GROUND-WATER-RECHARGE RATES IN NASSAU AND SUFFOLK COUNTIES, NEW YORK by David S. Peterson

U.S. GEOLOGICAL SURVEY

Water-Resources Investigations Report 86-4181

Prepared in cooperation with the

SUFFOLK COUNTY DEPARTMENT OF HEALTH SERVICES

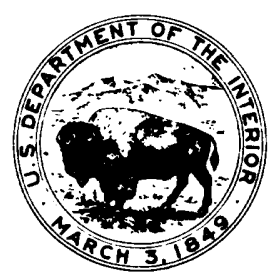

Syosset, New York 


\section{UNITED STATES DEPARTMENT OF THE INTERIOR}

DONALD PAUL HODEL, Secretary

GEOLOGICAL SURVEY

Dallas L. Peck, Director

For additional information write to:

U.S. Geological Survey

5 Aerial Way

Syosset, NY 11791

(516) $938-8830$
Copies of this report may be purchased from:

U.S. Geological Survey Books and Open-File Reports Federal Center, Bldg. 41

Box 25425

Denver, CO 80225

(303) 236-7476 


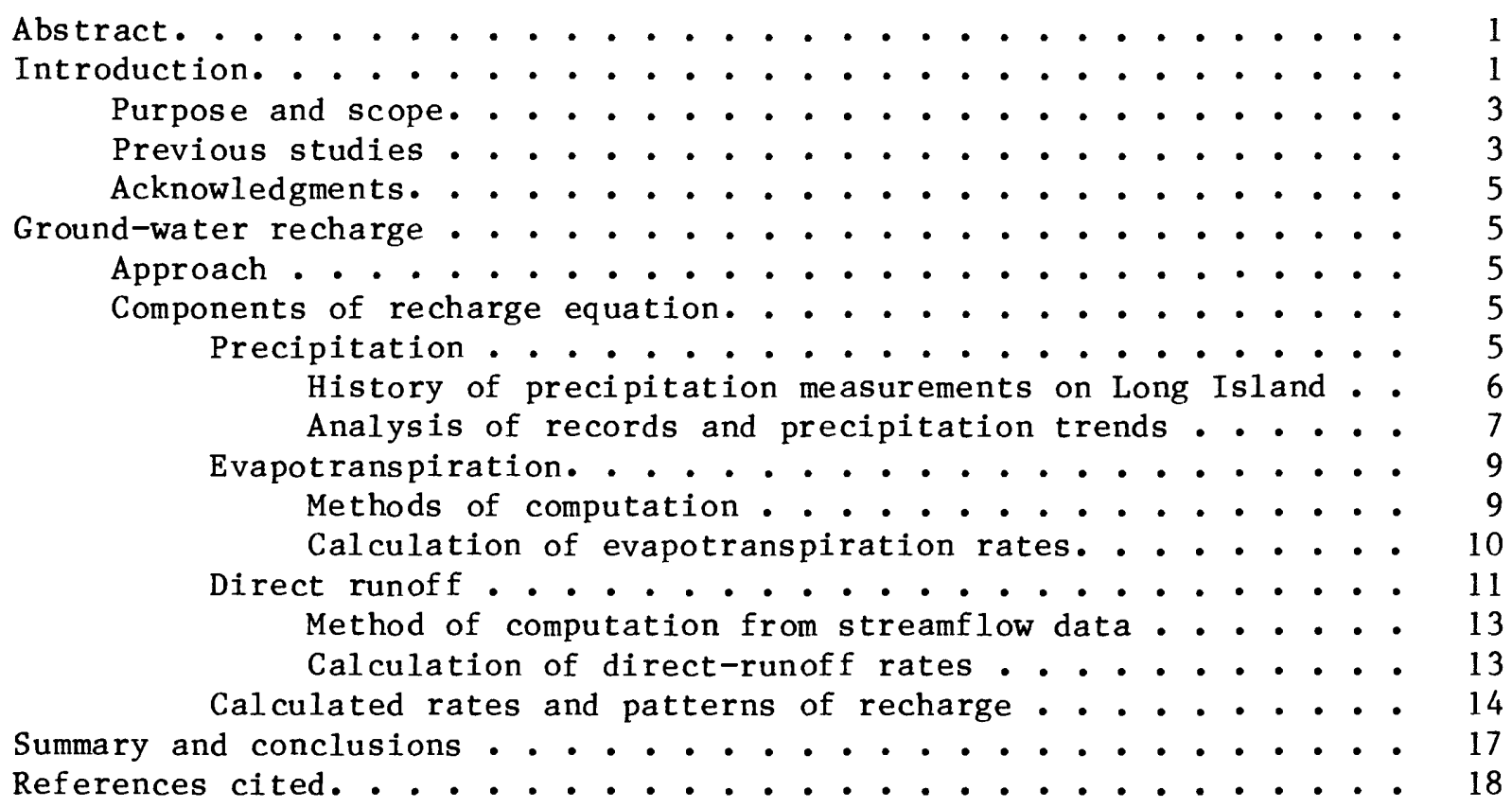

\section{ILLUSTRATIONS}

Figure 1. Map of Long Island showing location of study area and precipitation-measurement sites. . . . . . . . . . . 2

2. Graph showing annual precipitation at Setauket, 1886-1982. - 7

3. Map showing mean annual precipitation and station averages $\quad 8$

4. Map showing mean annual evapotranspiration rates . . . . 12

5. Map showing mean annual recharge rates . . . . . . . 15

\section{TABLES}

Table 1. Long-term monthly and annual precipitation at Mineola and Setauket. . . . . . . . . . . . . . . . . . 6

2. Evapotranspiration rates at eight Long Island weather stations, 1968-75 .................

3. Regional rates of ground-water recharge and other components calculated for this study ............... 


\section{CONVERSION FACTORS AND ABBREVIATIONS}

For readers who prefer to use metric (International System) units rather than the inch-pound units used in this report, values may be converted with the following factors:

Multiply inch-pound unit

by

inch (in.)

foot $(\mathrm{ft})$

square mile $\left(m i^{2}\right)$

cubic foot per second $\left(\mathrm{ft}^{3} / \mathrm{s}\right)$

million gallons per day per square mile

[(Mgal/d)/mi ${ }^{2}$ ]
25.4

0.3048

2.59

0.02832

1,460
To obtain metric unit

mill1meter (mm)

meter (m)

square kilometer $\left(\mathrm{km}^{2}\right)$

cublc meter per second $\left(\mathrm{m}^{3} / \mathrm{s}\right)$

cubic meter per day per square kflometer $\left[\left(\mathrm{m}^{3} / \mathrm{d}\right) / \mathrm{km}^{2}\right]$ 


\title{
GROUND-WATER RECHARGE RATES IN NASSAU AND SUFFOLK COUNTIES, NEW YORK
}

\author{
by David S. Peterson
}

\begin{abstract}
Ground water is the sole source of freshwater in Nassau and Suffolk Counties on Long Island; therefore, the rate at which precipitation replenishes the ground-water system may affect future water supplies in some areas. Annual precipitation on Long Island averages 45 inches per year, but less than 23 inches, or 50 percent, recharges the ground-water system. (Recharge is precipitation that percolates to the ground-water system naturally: it does not include water from stormwater basins or injection wells.) The rate of recharge varies locally and ranges from 29 to 57 percent of precipitation, depending on land use, season, and amount of storm sewering in the area. Recharge was calculated by subtracting evapotranspiration and direct runof $f$ values from known precipitation values. Evapotranspiration was calculated by the Thornthwaite and Mather method, and direct runoff rates to streams were calculated from streamflow records and size of known storm-sewer service areas. This report includes maps that depict precipitation, evapotranspiration, and rates of natural recharge in Nassau and Suffolk Counties for use in future hydrologic studies on Long Island.
\end{abstract}

\section{INTRODUCTION}

Long Island has a total area of about $1,400 \mathrm{mi}^{2}$. Kings and Queens Counties (fig. 1), which form the western $200 \mathrm{mi}^{2}$, are part of New York City and import most of their water from upstate reservoirs. Nassau and Suffolk Counties (fig. 1), which form the rest of the island, obtain their water from aquifers.

Nassau and Suffolk Counties rely totally on ground water as their source of freshwater, and precipitation is the only source of replenishment. Not all of the precipitation reaches the ground-water system, however; evapotranspiration and direct runoff (surface runoff to streams and surrounding water bodies through storm sewers) diminish the quantity of water available for recharge (water that percolates to the water table). Sanitary sewers and storm-sewer systems, which ultimately discharge to the sea, have decreased much of this replenishment and have caused a reduction in ground-water levels on the island. Construction of additional sewers will increase this effect. Thus, a thorough understanding of the rate of natural ground-water replenishment is needed for present and future water-management decisions by local and State governments.

In 1983, the U.S. Geological Survey, in cooperation with the Suffolk County Department of Health Services, studied available data and reviewed published values of several components of the hydrologic system on Long Island, then calculated new estimates of evapotranspiration and ground-water recharge rates to reassess the hydrologic balance. These new rates reflect 


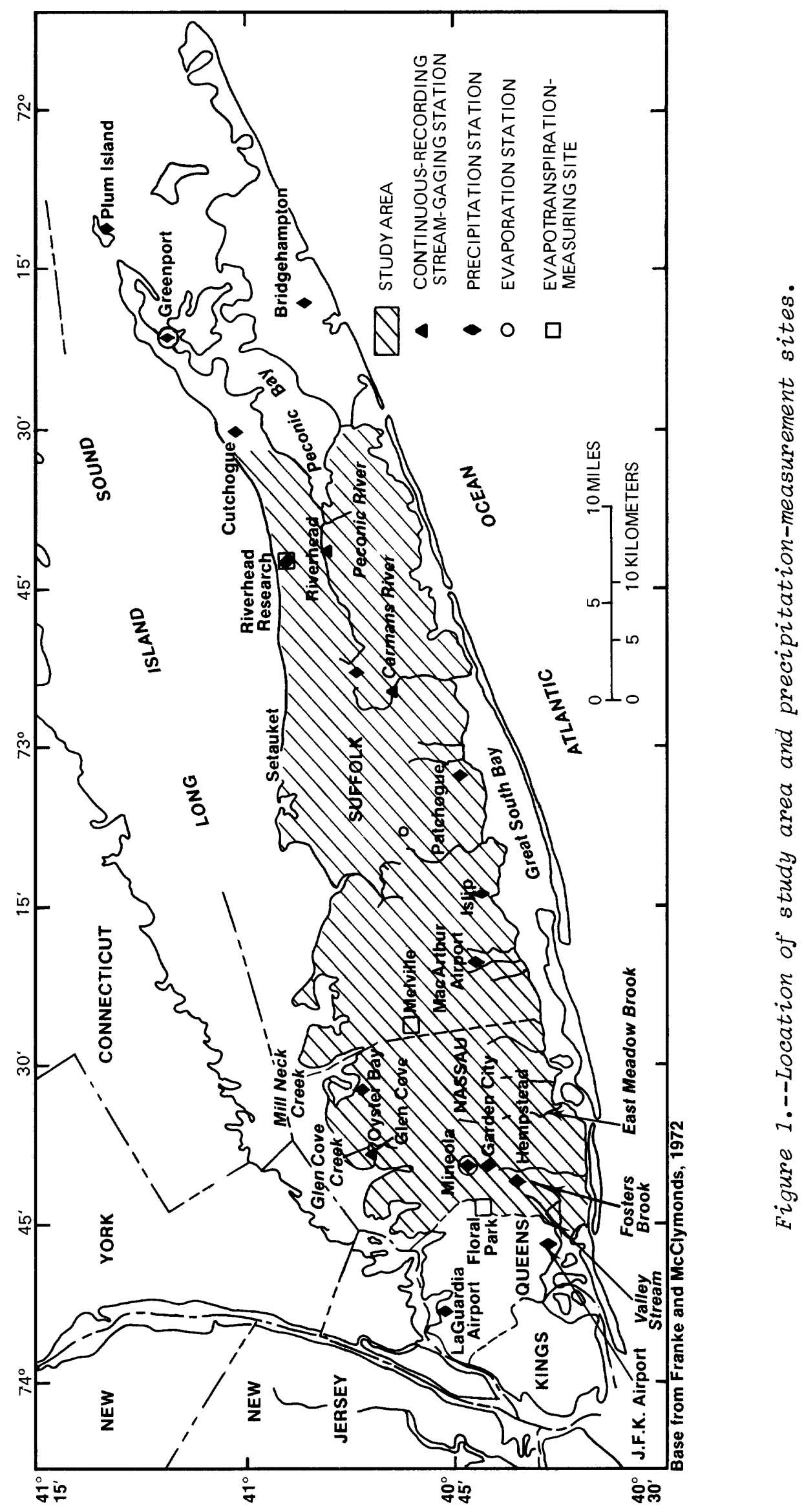


variations in climate, changes in land use, and types of soils across the island. Recharge is considered to be precipitation that reaches the groundwater system naturally. Because the amount of runoff that reaches the aquifers through recharge basins is essentially the same as that which would infiltrate the recharge basins' contributing drainage areas under natural conditions, the overall effect of recharge basins on rates of recharge was considered negligible in this study. Similarly, the effect of injection wells was considered negligible because the water they inject was initially ground water.

\section{Purpose and Scope}

The study entailed analysis of previous data and estimation of recharge rates on Long Island from recent values of precipitation, evapotranspiration, and direct runoff to streams. This report presents the results on maps that show local rates of natural recharge, evapotranspiration, and precipitation on Long Island. It also:

(1) Compares precipitation values given by Miller and Frederick (1969) with recent and long-term averages.

(2) Gives evapotranspiration rates for hydrologic sites from which precipitation and temperature data are available and for the entire Nassau-Suffolk study area. (The site-specific values were calculated from the tables of Thornthwaite and Mather (1957); the regional values were derived from temperature maps, land-use maps, and the site-specific values.)

(3) Gives rates of direct runoff to streams and tidewater as calculated from streamflow records and drainage-area maps.

(4) Presents recharge rates calculated from the above data sets. (The effect of recharge basins is considered negligible, as explained above.)

\section{Previous Studies}

Previous work on factors used to calculate ground-water recharge from precipitation has involved either analysis of field measurements or solution of a water-budget equation, in which many of the factors were regional estimates. Miller and Frederick (1969) and Bailey and others (1985) studied precipitation; others measured evapotranspiration or recharge in the field.

The first comprehensive precipitation study covering Long Island was done by Miller and Frederick (1969), who used records from 41 stations to analyze the 15-year period 1951-65. They used water years (October through September) in that study to provide a two-season analysis in which the "winter" season was 0ctober through March, and the "summer" season was April through September. Of the 41 stations used, 31 remained active in 1965. Miller and Frederick used a network of 10 of these stations for double-mass curve analysis between network stations and between the network stations and all other stations. For the network stations, they chose stations both on and of $f$ Long Island that had long and reliable records. They then applied a double-mass curve analysis to determine (1) whether a precipitation-recording 
site had undergone some change in environment or location that altered the record, and (2) how much adjustment should be made. They found that only two of the 41 stations needed adjustments.

Bailey and others (1985) used an area-averaging technique to derive precipitation values to construct a precipitation map. Values we re assigned to each element within a grid of triangular elements by averaging the values from the precipitation stations at the three node points of each element. This reduced potential "noise" factors that result from unique site characteristics and revealed regional trends. In contrast, lliller and Frederick (1969) used individual station estimates in the plotting analysis.

The precipitation map by Bailey and others (1985) was based on precipitation records of 1964-83. Their map uses a contour interval of 2 inches instead of the 1-inch intervals used by Miller and Frederick (1969) and for this study. Bailey and others (1985) were able to resolve questions arising from a lack of data in some areas in the Miller and Frederick study. l.ore detailed descriptions of methods of analysis, errors in measurements, and effects of possible future climatic events on Long Island are given in Bailey and others (1985).

Some previous investigators estimated average annual evapotranspiration by closing the hydrologic budget. For many, this required use of an estimated or calculated value of recharge. Others, using selected drainage basins, took evapotranspiration to be the difference between precipitation and stream discharge in that basin.

The first experiment to measure evapotranspiration directly on Long Island was done in 1903 at Floral Park in Nassau County (fig. 1) for New York City (Burr and others, 1904). In this experiment, a metal tank containing a column of soil was placed in the ground to maintain ground temperature, and the column was frequently weighed to determine changes in water content. Evapotranspiration losses could be calculated from the resulting precipitation value.

Two important evaporation-and-recharge studies have been done on Long Island--one by Holzmacher, McLendon, and liurrell (1970), who undertook a lysimeter experiment in 1968 at Melville (fig. 1), and one by Steenhuis and others (1983) at the Cornell University Horticultural Research Farm at Riverhead (fig. 1), which did a micrometeorological study in cooperation with the Suffolk County Department of Health Services in 1979-81.

The Holzmacher, McLendon, and Murrel1 (1970) study used a 4-ft-deep lysimeter tank in a bluegrass plot in llelville. A 4-inch-diameter rain gage at the site provided precipitation data; air-temperature data consisted of the average values at the Hempstead, Garden City, and llineola weather stations. Water was periodically added to the tank by flooding to supplement precipitation and to guarantee sufficient water ( 30 inches) to meet the potential evapotranspiration requirements.

The study by Steenhuis and others (1983) used micrometeorological data and field tests to develop an alternative method for approximating natural recharge. This study indicated that the annual recharge equaled 90 percent of the total precipitation that falls from October 15 through May 15. 


\section{Acknowledgments}

The author thanks the Drainage Division of the Nassau County Department of Public Works and the Suffolk County Department of Health Services, both of which provided maps and information on storm sewers and drainage areas.

\section{GROUND-WATER RECHARGE}

Much of the precipitation on Long Island never reaches the ground-water system because it is lost through evapotranspiration and as direct runoff. The remainder--the amount that infiltrates the land surface and percolates to the water table and the ground-water system--is considered natural recharge and can be calculated from the following equation:

$$
\text { Recharge }=\text { Precipitation - Evapotranspiration - Direct Runof } f
$$

In this report, all values in the above equation are mean annual values, expressed as inches per year.

Urbanization has interfered with the process of natural recharge on Long Island. Storm sewers conduct runoff from precipitation to streams, tidewater, and recharge basins; thus, recharge basins and injection wells cause a redistribution of runoff within the natural system. Their effect on total recharge was considered negligible in this study, however, and natural recharge is referred to simply as recharge throughout this report.

\section{Approach}

Values of precipitation, evapotranspiration, and direct runoff were assigned for each block in a grid system currently being used for a U.S. Geological Survey regional ground-water computer model of Long Island. The blocks in the grid represent 4,000 ft x 4,000 ft of land surface. Rates of recharge were calculated from the three factors in the above equation.

Evapotranspiration and direct-runoff rates were calculated from climatic and streamflow data from 1968-75. Although this period spans only 8 years, it represents average conditions, reflects a complete recovery from the 1962-66 drought, and excludes the high-water years of the late 1970's and therefore was considered valid.

\section{Components of Recharge Equation}

\section{Precipitation}

Precipitation is fairly evenly distributed throughout the year (table 1); thus, no distinct wet or dry seasons can be distinguished. Much of the winter precipitation is caused by low-pressure systems that move northeastward along the Atlantic coast. Accompanied by strong winds, such low-pressure storm systems are known as "northeasters." Either rain, snow, or sleet can develop, 
depending on air temperature. Cold air sweeping southeastward around eastward-moving lows in the St. Lawrence valley can result in light showers or snow flurries. Summer precipitation is largely the result of thunderstorms or showers that generally are associated with the passage of cold fronts.

Tropical storms that affect Long Island occur between June and November. Although many tropical storms bypass Long Island, they can cause significant precipitation.

Long Island has had more than 60 precipitation-recording sites in this century, but many sites have records for only 2 or 3 years and cannot be considered useful for islandwide analysis. In January 1985, 36 stations were in operation. Most are kept by private citizens under the auspices of local or Federal agencies and are fairly evenly distributed across the island.

\section{Table 1.--Long-term monthly and annual average precipitation at Mineola and Setauket, Long Island, New York}

[A11 values are in inches; locations are shown in fig. 1.]

\begin{tabular}{lcc}
\hline Month & $\begin{array}{c}\text { Mineola } \\
(1938-83)\end{array}$ & $\begin{array}{c}\text { Setauket } \\
(1886-1983)\end{array}$ \\
\hline January & 3.37 & 3.81 \\
February & 3.29 & 3.47 \\
March & 4.20 & 4.10 \\
April & 4.01 & 3.87 \\
May & 3.55 & 3.54 \\
June & 3.19 & 3.18 \\
July & 3.60 & 3.64 \\
August & 4.01 & 4.03 \\
September & 3.65 & 3.63 \\
October & 3.28 & 3.60 \\
November & 3.94 & 3.90 \\
December & 3.79 & 3.98 \\
Average yearly & & \\
total & & \\
\hline
\end{tabular}

History of precipitation measurements on Long Island.--Precipitation measurements are subject to errors from several sources, and the errors tend to produce values that are lower than the actual values. The greatest source of error is wind. Because most rain gages are above ground, wind can cause updrafts that diminish the catch, which can result in underestimation of precipitation amounts. Therefore, the amounts of precipitation and rates of evapotranspiration and recharge given herein can be considered somewhat conservative. Measurement errors are discussed in Bailey and others (1985).

The longest records for the Long Island area are those recorded in New York City since 1826 and now kept by the National Oceanic and Atmospheric Administration (NOAA). The New York City record includes site-location changes, however, and therefore, is not a true continuous record. The longest continuous precipitation record on Long Island was collected at the NOAA 
station at Setauket in Suffolk County (fig. 1); records extend from 1886 to the present. A hydrograph of annual precipitation at Setauket during 1886-1982 is given in figure 2. Precipitation records for Cutchogue, also in Suffolk County, begin in 1899 but are discontinuous.

Sources of Long Island precipitation data include Nassau County Department of Public Works, Suffolk County Department of Health Services, Suffolk County Water Authority, various towns, corporations, private citizens, NOAA, and the U.S. Geological Survey. These records, although numerous, are difficult to correlate because many precipitation-recording sites were operated for only a few years, and others were discontinued or relocated after many years of reliable record.

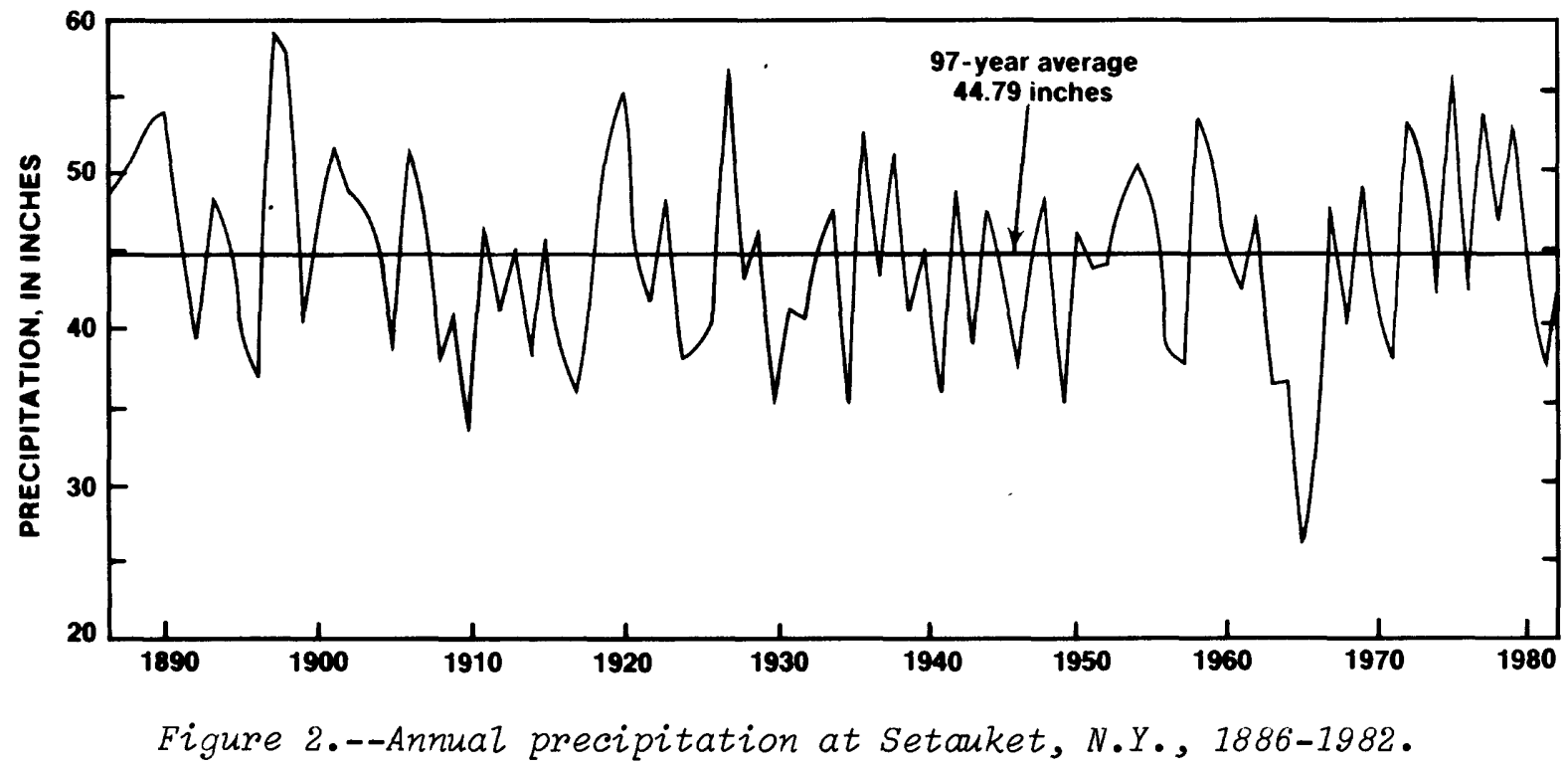

Analysis of records and precipitation trends.--Comparison of daily and monthly records of neighboring stations indicates that many storms on Long Island have been local. Frequently, a local storm will increase the yearly value for that site substantially; thus, for that year, the station's record will not correlate with records of nearby stations.

The 1962-66 drought resulted from the longest period of low precipitation ever recorded on Long Island, and 1965 had the lowest single yearly values at all stations except the station at the Riverhead Research Farm.

The annual mean values of precipitation at longer tern precipitation stations closely match the values on the 1951-65 maps by Miller and Frederick (1969) (fig. 3), mostly within a few tenths of an inch. This and the fact that the effect of the 1962-66 drought was largely balanced by the above-average precipitation in the 1950's indicate that the 1951-65 meanprecipitation maps can be used to represent other periods.

Three of the five stations at which the long-term mean seems significantly less than the 1951-65 mean are in eastern Suffolk County. The Bridgehampton, Riverhead, and Plum Island stations on Miller and Frederick's 


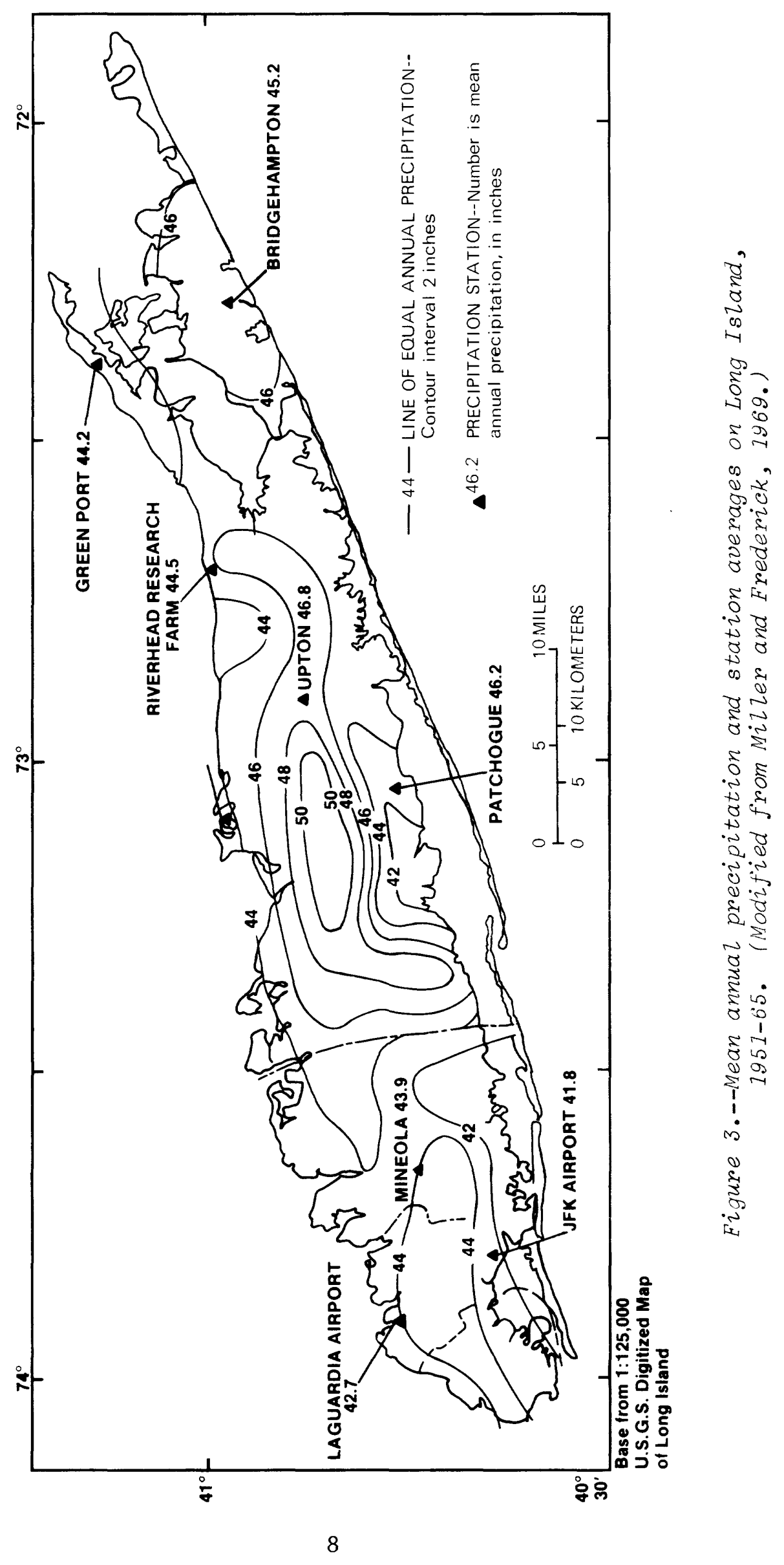


mean precipitation nap (1969) are approximately 2 inches above both the long-term mean and the 1966-80 mean. However, 2 inches over the entire year is only a 4-percent difference and cannot be considered significant in that stations around each of the three stations do not show the same trend. The station at llacArthur Airport in Islip has lower values than expected but begins its period of record in 1963--the second year of the drought; this can account for some of the deficit. The station with the greatest discrepancy is at Oyster Bay in Nassau County. This station has a long-tern mean of 50 inches, whereas the map of mean annual values shows approximately $43.6 \mathrm{in} / \mathrm{yr}$. The 50-inch value compares more favorably with the 48-inch inferred contour line on the map by Bailey and others (1985).

\section{Evapotranspiration}

Evapotranspiration is the most difficult factor to quantify in the hydrologic cycle on Long Island. It is defined as the natural loss of water by evaporation and by transpiration by plants. In the natural recharge regime, evaporation occurs from water, soil, snow, ice, and plant surfaces, and transpiration is a biological process in which water is absorbed by plant roots from the soil, is circulated through the plant, and is discharged to the atmosphere from the leaves as vapor. Several meteorologic, biologic, and geographic characteristics are involved in the evapotranspiration process; these include air temperature, humidity, solar radiation, length of growing season, wind movement, topography, soil type, soil moisture, amount and type of precipitation, and type of vegetation.

Methods of computation.--Recharge is the factor of primary concern in a water budget for Long Island; therefore, an estimate of evapotranspiration based on independent and reliable data is necessary. Some investigators have estimated average annual evapotranspiration by developing a hydrologic budget, which generally is based on an estinated or calculated value of recharge. Others have studied evapotranspiration in selected drainage basins and have determined that evapotranspiration is the difference between precipitation and stream discharge from that basin.

llany of the evapotranspiration studies made throughout the world have been done in arid or semiarid areas, where precipitation is low compared with that on Long Island. The moist climate of Long Island, along with its highly permeable soils and extensive crop growth and irrigation, renders nany widely used estimation methods ineffective.

The tables developed by Thornthwaite and Mather (1957) are one of the more reliable tools for estimating evapotranspiration on Long Island. In 1948, Thornthwaite correlated mean monthly air temperature with evapotranspiration in water-balance studies in the east-central United States and introduced the concept of "potential evapotranspiration." This assumes that, if sufficient moisture is present, the maximun evapotranspiration losses will be a function of available energy. The energy is provided mainly by air temperature and solar radiation; wind and humidity play only a small part. The method distinguishes between potential and actual evapotranspiration when insufficient precipitation has caused a soil-moisture deficiency. (At such times, the actual evapotranspiration is less than the potential.) On Long Island, this is common in summer, when the water held in the soil by capillary 
action (field capacity) is withdrawn from the root zone. In the fall, the process reverses as vegetation dies or becomes dormant, and the moisture content of the root zone returns to field capacity.

A study by Holzmacher, McLendon, and Murrell (1970) on Long Island provided an evapotranspiration estimate of 18.7 inches for May through August. The value calculated from tables of Thornthwaite and Mather (1957) for the same period was 19.0 inches. Although the 1970 study covered only a 4-month period, Holzmacher, McLendon, and Murrell considered the close match of results a verification of the usefulness of the tables developed by Thornthwaite and Mather for Long Island.

Calculation of evapotranspiration rates.--Values of average evapotranspiration for 1968-75 computed from the Thornthwaite and Mather tables for several sites on Long Island are presented in table 2. (These sites are weather stations from which precipitation and temperature data are available.) Soil type and depth of root zones at each location were included in the calculations. Although table 2 represents only 8 years, this period can be considered average because it had no extreme conditions such as drought or excess precipitation.

Table 2.--Evapotranspiration rates at eight Long Island weather stations, 1968-75, calculated from Thornthwaite and Mather (1957)

\begin{tabular}{|c|c|c|c|c|c|}
\hline \multicolumn{6}{|c|}{ [Locations are shown in fig. 1] } \\
\hline Station & Soil type & Vegetation & $\begin{array}{l}\text { Evapo- } \\
\text { transpiration } \\
\text { (inches) }\end{array}$ & $\begin{array}{l}\text { Evapo- } \\
\text { transpiration, } \\
\text { as percentage } \\
\text { of precipitation }\end{array}$ & $\begin{array}{l}\text { Soll-moisture } \\
\text { retention } \\
\text { (inches) }\end{array}$ \\
\hline Bridgehampton & $\begin{array}{l}\text { sandy loam } \\
\text { silt loam }\end{array}$ & $\begin{array}{l}\text { shallow root } \\
\text { shallow root }\end{array}$ & $\begin{array}{l}21.2 \\
21.4\end{array}$ & $\begin{array}{l}46.6 \\
47.2\end{array}$ & $\begin{array}{l}3 \\
5\end{array}$ \\
\hline $\begin{array}{l}\text { LaGuardia } \\
\text { Airport }\end{array}$ & $\begin{array}{l}\text { sand } \\
\text { c Jay loam } \\
\text { sandy loam }\end{array}$ & $\begin{array}{l}\text { shallow root } \\
\text { shallow root } \\
\text { moderate root }\end{array}$ & $\begin{array}{l}24.2 \\
25.4 \\
26.2\end{array}$ & $\begin{array}{l}52.9 \\
55.5 \\
57.2\end{array}$ & $\begin{array}{l}2 \\
4 \\
6\end{array}$ \\
\hline JFK Ai rport ${ }^{1}$ & $\begin{array}{l}\text { sand } \\
\text { clay loam } \\
\text { sandy loam }\end{array}$ & $\begin{array}{l}\text { shallow root } \\
\text { shallow root } \\
\text { moderate root }\end{array}$ & $\begin{array}{l}22.5 \\
23.9 \\
25.0\end{array}$ & $\begin{array}{l}53.8 \\
57.3 \\
60.0\end{array}$ & $\begin{array}{l}2 \\
4 \\
6\end{array}$ \\
\hline Mineola & $\begin{array}{l}\text { sand } \\
\text { sandy-silt loam } \\
\text { sandy loam } \\
\text { sandy loam }\end{array}$ & $\begin{array}{l}\text { shallow root } \\
\text { shallow root } \\
\text { moderate root } \\
\text { orchards }\end{array}$ & $\begin{array}{l}22.4 \\
23.8 \\
25.1 \\
25.5\end{array}$ & $\begin{array}{l}47.8 \\
51.0 \\
53.7 \\
54.5\end{array}$ & $\begin{array}{r}2 \\
4 \\
6 \\
10\end{array}$ \\
\hline Patchogue & fine sand & mature forest & 25.5 & 53.5 & 10 \\
\hline Riverhead & sandy loam & $\begin{array}{l}\text { shallow root } \\
\text { orchards }\end{array}$ & $\begin{array}{l}22.4 \\
24.8\end{array}$ & $\begin{array}{l}49.3 \\
54.7\end{array}$ & $\begin{array}{r}3 \\
10\end{array}$ \\
\hline Setauket & sandy loam & mature forest & 26.8 & 57.9 & 12 \\
\hline Upton & $\begin{array}{l}\text { silt loam } \\
\text { sandy loam }\end{array}$ & $\begin{array}{l}\text { deep root } \\
\text { moderate to } \\
\text { deep root }\end{array}$ & $\begin{array}{l}23.9 \\
23.0\end{array}$ & $\begin{array}{l}48.4 \\
46.5\end{array}$ & $\begin{array}{r}10 \\
6 \\
\end{array}$ \\
\hline
\end{tabular}

1 John F. Kennedy International Airport 
llost soils on Long Island are permeable and sandy and have a low field capacity. A 2.5-ft-thick root zone with a total of 2 to 3 inches of available water is considered average for the Island (Holzmacher, McLendon, and Murrell, 1970). These values vary locally, however.

The percentages of precipitation lost through evapotranspiration (table 2) were used as guidelines to construct the evapotranspiration map shown in figure 4 and to assign evapotranspiration rates, in in./yr, to a grid. Three criteria--soil type, air temperature, and land use--were used to determine which percentage was to be applied to each block. Soil maps (Lounsbury and others, 1928; U.S. Department of Agriculture, 1975) were inspected for location of soil types. Seasonal temperature maps (U.S. Department of Commerce, 1974) were used to assign an evapotranspiration rate from a station with similar temperature (from table 2) to areas without temperature data. The 1981 land-use map of the Long Island Regional Planning Board (1982) provides a detailed rendition of land-use patterns in Nassau and Suffolk Counties. The land-use maps were used to determine the type of vegetation and the percentage of area covered by vegetation. Areas with a large amount of paved surface lose little water through evapotranspiration because paved surfaces generally contain little vegetation and because the increased runof $f$ decreases infiltration. In general, the higher the degree of development, the smaller the evapotranspiration value.

The evapotranspiration rates in the southern and central parts of Long Island, which are mantled by permeable outwash sand and gravel, are generally smaller than those in the north-shore area, which contains less permeable till, more trees (which tend to have deep root zones), and more soils with a greater field capacity than those on the south shore.

\section{Direct Runoff}

Generally, undisturbed sandy soils of Long Island absorb precipitation readily. Urbanization increases the amount of land covered by impervious surfaces, however, and this increases direct runoff. In urbanized parts of Long Island, much of the precipitation that falls near streams enters the streams either as overland runoff or through storm sewers, and then flows to tidewater.

lluch of the storm runoff that does not enter streams or tidewater flows to recharge basins or leaching pools, from which it percolates to the water table. Several studies of the effects and efficiency of recharge basins on Long Island have been completed. A study of more than 2,000 recharge basins by Seaburn and Aronson (1974) suggests that, in areas where recharge basins are used to dispose of storm water, ground-water recharge from precipitation is probably equal to and may slightly exceed recharge under natural conditions because the extensive paving in such areas reduces evapotranspiration. Thus, if we assume that the amount of water that now reaches the basins would be the same under predevelopment conditions, the overall effect of the recharge basins could be considered zero. Therefore, recharge rates for areas drained by recharge basins were calculated as if natural recharge conditions prevailed. No precipitation was considered lost to storm-sewer systems in contributing drainage areas, nor were any positive or negative effects of basins on total volumes of recharge considered. 


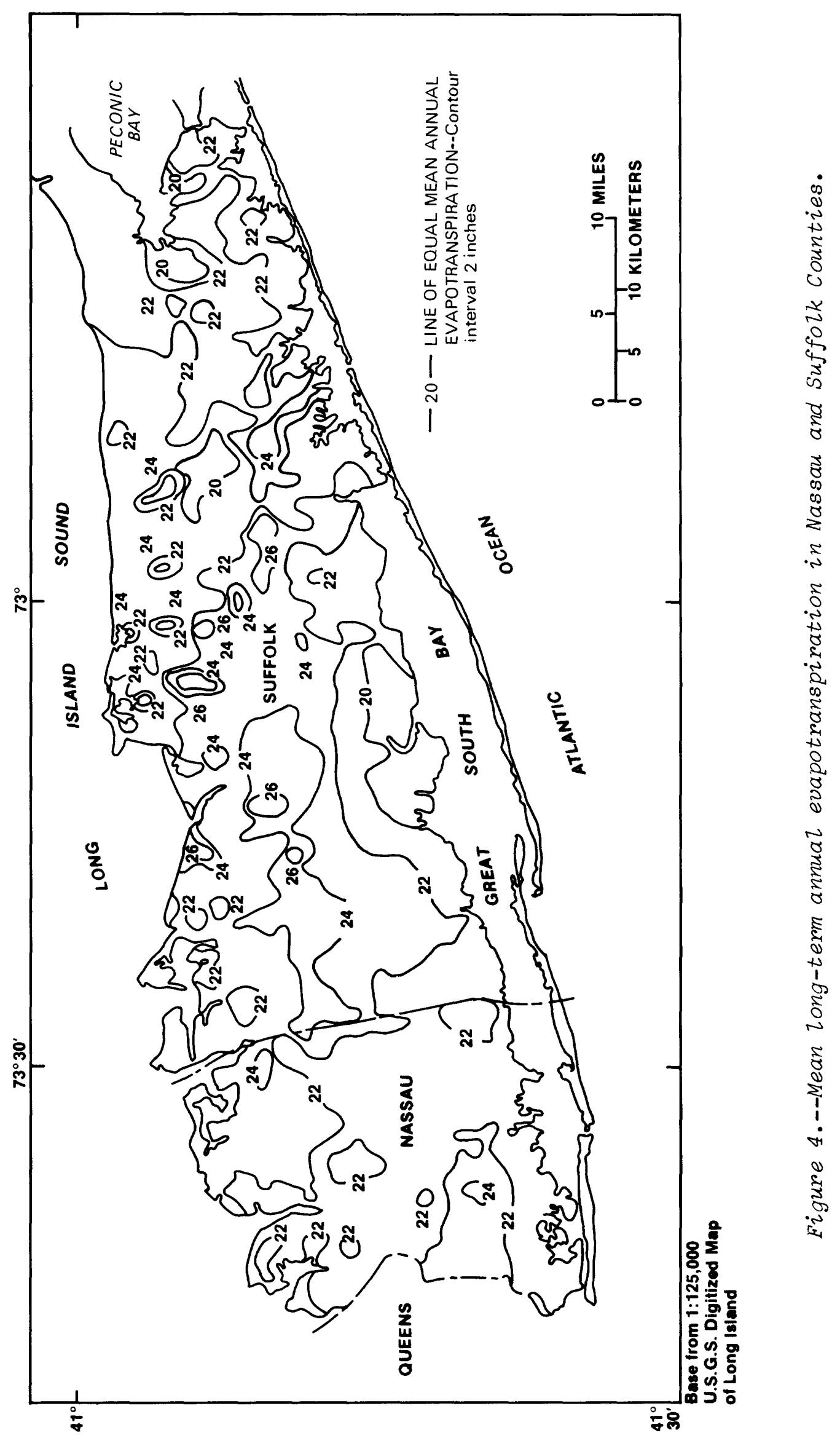


Method of computation from streamflow data.--Direct runoff of precipitation to streams was calculated as the difference between total flow and base flow. (Base flow is that part of a stream's flow that is contributed from the ground-water system.) Although the two-county study area contains more than 130 streams on which flow data are available, only 16 have continuous records for the entire 1968-75 period. To obtain a base-flow value for each stream, Reynolds (1982) used a method of hydrograph separation discussed by Chow (1964) for all continuously gaged streams for water years 1960-75, then used the average of the $1968-75$ base flows to calculate a mean annual direct-runoff figure for the continuous-record streans.

Base-flow values for partial-record streams were calculated through a statistical correlation method described by Buxton (1985), who computed the base flow in partial-record streams along the south shore of Long Island. The continuously gaged streams are distributed across the island between groups of partial-record streams. Base flow, expressed as a percentage of total flow, reflects the degree of urbanization, topography, and other characteristics of the environment. The base-flow values of south-shore streams on Long Island differ greatly. For example, Valley Stream in western Nassau County (fig. 1) flows through a densely populated suburban area, and the base flow during 1968-75 constituted 10.4 percent of the total flow. In contrast, the base flow of Carmans River, in an undeveloped area of eastern Suffolk County, constituted 95 percent of the total flow during the same period. On the north shore of Long Island, the steeper slopes increase the amount of direct runoff to the streams, even in unurbanized areas. Base flow of Mill Neck Creek, which flows through a region of estates and little development in Nassau County, constitutes 85 percent of the total flow.

Direct runoff to the partial-record streams was calculated from the base-flow and direct-runoff percentages fron the continuously gaged streams that are closest and most representative of the environment of each partial-record stream.

Calculation of direct-runoff rates.--Direct runoff to each stream, in $\mathrm{ft} / \mathrm{s}$, was converted to a rate of water flowing over the drainage basin, in inches per year, for incorporation into a regional grid. This required information on the size of the areas contributing runof $f$ to each stream. On Long Island, many of the drainage areas of streams differ from the areas that contribute storm runoff. Storm-sewer systems on Long Island have been constructed so that many topographic drainage areas that originally were drained by one stream are now drained by a number of streams or constructed drains. Therefore, stormwater of ten bypasses normal runoff routes.

The Suffolk County Department of Health Services has mapped both the topographic and stormwater-contributing areas to streans and tidewaters in Suffolk County, and the Nassau County Department of Public Works, Drainage Division, has mapped many storm-sewer drainage areas. Data from these two departments were compiled on one map in this study. Runoff areas in Suffolk County could be used directly, whereas the runoff areas in western Nassau County were adjusted to avoid the upper channels of some streams that are highly permeable or have dry streambeds over long distances. A study on Fosters Brook in Nassau County ( $f i g \cdot 1$ ) by Prince (1982), in which a sustained flow of pumped ground water was applied to an initially dry streambed, indicated rapid infiltration. Therefore, even though these contributing areas 
are significant during severe storms, they were not considered in calculations of direct runoff to some streams in western Nassau County.

Initially, the strean-gage locations were used to mark the shoreward extent of the runoff areas. A few of the continuously gaged streams also had a downstream partial-record gage. It was found that data collected at these gage sites yielded the same runoff rates. Therefore, the upstream rate was applied to the area below the gages on many streams. This method was also applied to nearshore land that had some degree of development. It was assumed that direct runof $f$ was insignificant in undeveloped nearshore areas because the sandy soil is highly permeable and because few, if any, storm sewers have been installed there.

Increasing urbanization will probably cause direct run of $f$ to increase. High rates of runoff to streams were found in southern Nassau County, parts of southwestern Suffolk County, in the City of Glen Cove around Glen Cove Creek (fig. 1), and at Riverhead near the mouth of the Peconic River (fig. 1). A detailed analysis of the effects of urban development on direct runof $f$ is given by Seaburn (1969), who documents the changes in East lleadow Brook during 1937-62.

\section{Calculated Rates and Patterns of Recharge}

The percentage of precipitation that becomes recharge can vary widely on Long Island because precipitation varies temporally and locally. The amount of precipitation has a direct bearing on evapotranspiration and direct runof $f$ rates, which, together with climatic and geographic factors, cause considerable fluctuations in natural recharge.

Estimates given in the preceding sections on precipitation, evapotranspiration, and direct runof $f$ were used to calculate annual rates of recharge for each of the two counties (table 3 ). The map showing calculated recharge rates

Table 3.--Regional ground-water recharge rates and other components calculated in this study

\begin{tabular}{|c|c|c|c|}
\hline Component & $\begin{array}{l}\text { Nassau } \\
\text { County }\end{array}$ & $\begin{array}{l}\text { Suffolk } \\
\text { County }\end{array}$ & $\begin{array}{l}\text { Long } \\
\text { Island }\end{array}$ \\
\hline PRECIPITATION (inches) & 43.3 & 45.9 & 45.2 \\
\hline \multicolumn{4}{|l|}{ RECHARGE } \\
\hline Total (inches) & 20.6 & 23.5 & 22.7 \\
\hline precipitation & 47.6 & 51.2 & 50.2 \\
\hline \multicolumn{4}{|l|}{ EVAPOTRANSP IRATION } \\
\hline Total (inches) & 21.8 & 22.1 & 22.1 \\
\hline precipitation & 50.3 & 48.1 & 48.8 \\
\hline \multicolumn{4}{|l|}{ DIRECT RUNOFF } \\
\hline $\begin{array}{l}\text { Total (inches) } \\
\text { Percentage of total }\end{array}$ & .9 & .3 & .4 \\
\hline precipitation & 2.1 & .7 & 1.0 \\
\hline
\end{tabular}




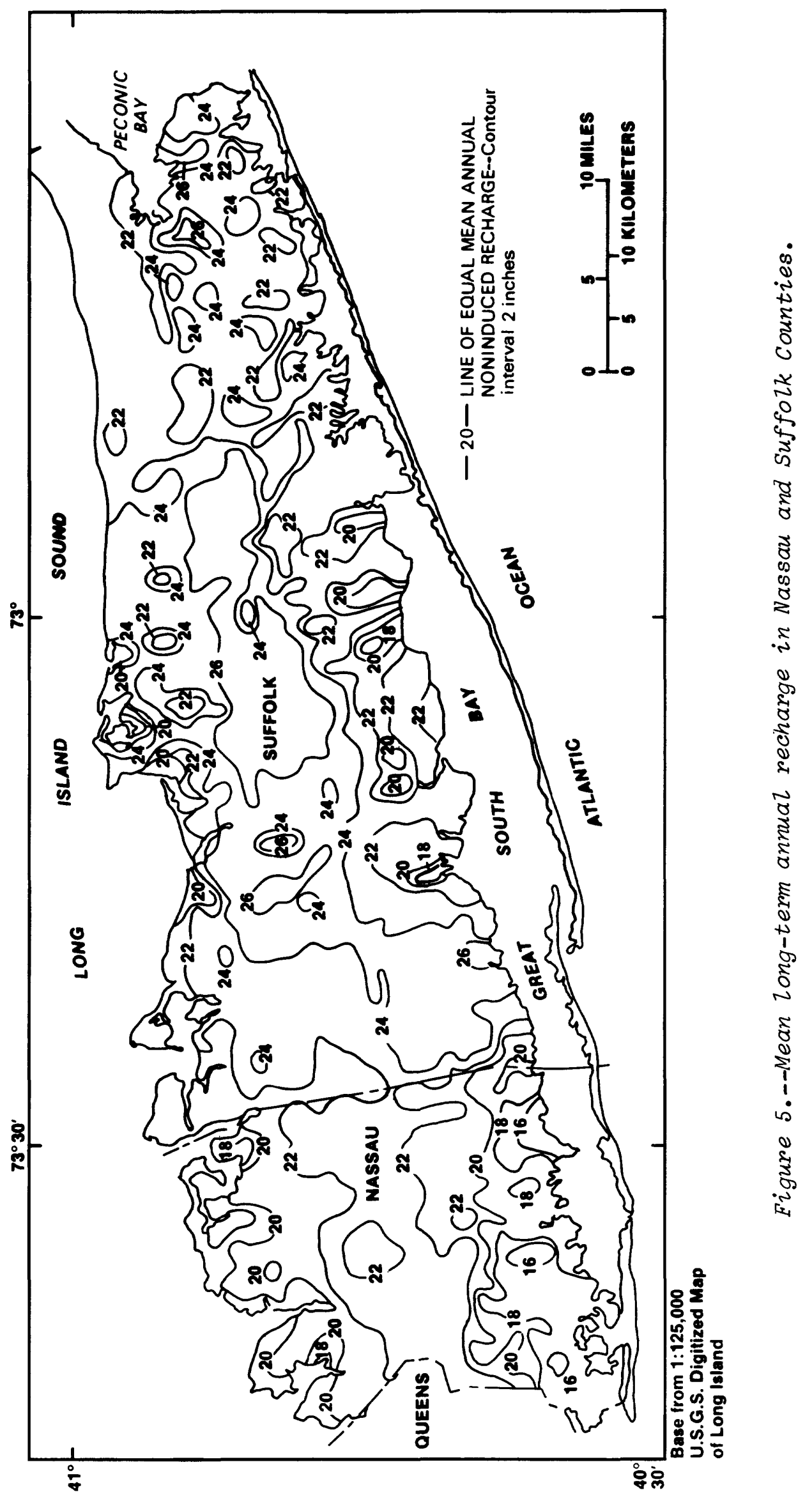


(fig. 5) reflects the effects of urbanization. The urbanized areas in southern Nassau County and along most of the north-shore peninsulas have low recharge rates; the lowest are slightly more than $12 \mathrm{in} / \mathrm{yr}$ in the highly developed southwestern part of the County. In general, Nassau has lower rates of recharge than Suffolk, and all grid blocks receive less than $24 \mathrm{in} / \mathrm{yr}$. Rates in Suffolk County range from 14.3 to $27.0 \mathrm{in} / \mathrm{yr}$ and correlate closely with the mean annual precipitation map ( $f i g .3$ ) used in this study. The higher values in southwestern Suffolk on the Miller and Frederick map (1969) hide the effects of urbanization and indicate high recharge rates of about 25 in/yr in that area. This contrasts sharply with the south shore of Nassau to the west and south-central Suffolk to the east. If precipitation is based on the map of Bailey and others (1985), the two areas of high recharge in Suffolk could average 2 to 3 inches less per year.

In general, estimates of mean annual recharge by previous investigators are equal to about one-half of the mean annual precipitation, or 22 to 23 $\mathrm{in} / \mathrm{yr}$. This amounts to about $1(\mathrm{Mgal} / \mathrm{d}) / \mathrm{mi}^{2}$. The average recharge for the two-county area studied is 50.2 percent of total precipitation or 1.08 $(\mathrm{Mgal} / \mathrm{d}) / \mathrm{mi}^{2}$. This estimate compares favorably with the $1.05(\mathrm{Mgal} / \mathrm{d}) / \mathrm{mi}^{2}$ of Franke and McClymonds (1970) and the $1.12(\mathrm{Mgal} / \mathrm{d}) / \mathrm{mi}^{2}$ of Porter and Baskin (1977). Both estimates represent a watershed area consisting of Nassau County and western and central Suffolk County, excluding the coastal areas. Porter and Baskin (1977) analyzed recharge from the land-use maps of the Long Island Regional Planning Board and calculated runoff from the amount of paved-surface area. The "90-percent method" of Steenhuis and others (1983) uses the 1968-75 record from Mineola, Patchogue, and Setauket as representative stations for Long Island and gives recharge values of $50.7,54.6$, and 54.1 percent of the annual precipitation, respectively. If direct runoff were included as a factor, these figures would be somewhat lower for Mineola and Patchogue and would compare favorably with the overall 50.2-percent value above.

Some or all of the above recharge figures may be considered conservative because precipitation measurements on which they are based generally contain some error. Other factors used in calculating recharge are based on precipitation measurements also; thus the resulting evapotranspiration and recharge maps (figs. 4 and 5) provide conservative values. A need remains for future studies to fully assess errors in precipitation measurements and to obtain evapotranspiration rates from actual measurements across Long Island. 


\section{SUMMARY AND CONCLUSIONS}

Precipitation is the source of replenishment for aquifers in Nassau and Suffolk Counties, where ground water is the sole source of freshwater. Assessment of the hydrologic balance on Long Island requires information on how much precipitation reaches the ground-water system. Some of this precipitation does not reach the ground-water system because it is lost through evapotranspiration and as direct runoff to streams. Previous work on precipitation has been done on a regional basis, and evapotranspiration and recharge have been studied locally.

The extensive network of weather stations across Long Island provides ample data on rates of precipitation. Long-term averages generally match the values shown on the mean-annual precipitation maps of Miller and Frederick (1969), who used 1951-65 as a base period. Bailey and others (1985), using more recent data, different analytical methods, and the 1964-83 base period, have improved the record of Long Island precipitation where data were lacking during the Miller and Frederick study. However, the Miller and Frederick maps were the only maps available during most of this study and proved adequate in depicting long-term precipitation conditions for most of Long Island.

Evapotranspiration rate generally is an unknown factor. A few reliable studies have been done to measure evapotranspiration directly in the field, and several calculation methods are available that use other climatic data. In this study, rates calculated from tables of Thornthwaite and Mather (1957) were used along with land-use, soil, and air-temperature maps to assign evapotranspiration values to a grid of Nassau and Suffolk Counties. Each grid block represented a 4,000 x 4,000-ft ${ }^{2}$ area.

Streamflow records were used to calculate direct runoff to Long Island streams. The runoff values, applied to the stormwater-contributing areas that drain to the streams, yielded annual direct-runoff rates. Runoff proved to constitute a significant loss of recharge in urbanized areas that lack recharge basins.

Natural recharge was calculated by subtracting evapotranspiration and direct-runoff losses to tidewater from precipitation. The rates were assigned to the grid, and mean annual evapotranspiration and recharge maps were drawn from the grid.

Data presented herein confirm the validity of using 50 percent of precipitation as the recharge value on Long Island. A recharge rate of 50.2 percent of precipitation or $22.7 \mathrm{in} / \mathrm{yr}$ was calculated for Nassau and Suffolk Counties, excluding the eastern forks and islands. However, as indicated by the recharge map (fig. 5), the percentage of recharge varies locally, depending on the climate and geography. Natural recharge rates were found to increase from west to east and toward the interior of the island. 


\section{REFERENCES CITED}

Bailey, B. H., Webster, Kenneth, and Stewart, Ronald, 1985, Long Island precipitation patterns and drought probability: State University of New York at Albany, Atmospheric Sciences Research Center, publication no. $1000,71 \mathrm{p}$.

Burr, W. H., Hering, Rudolph, and Freeman, J. R., 1904, Report of the Commission on additional water supply for the City of New York: New York, Martin B. Brown Company, 980 p.

Buxton, H. T., 1985, Estimating average base flow at low-flow partial-record stations, Long Island, New York: U.S. Geological Survey Water-Resources Investigations Report 84-4240, $32 \mathrm{p}$.

Chow, V. T., ed., 1964, Handbook of applied hydrology: New York, McGraw Hil1, $1118 \mathrm{p}$.

Franke, 0. L, and McClymonds, N. E., 1972, Summary of the hydrologic situation on Long Island, New York, as a guide to water-management alternatives: U.S. Geological Survey Professional Paper 627-F, 59 p.

Holzmacher, McLendon, and Murre11, Engineers, 1970, Comprehensive public water supply study, Suffolk County, New York: Melville, N.Y., Holzmacher, McLendon, and Murre11, CPWS-24, v. 2, 373 p.

Long Island Regional Planning Board, 1982, Land use--1981, quantification and analysis of land use for the Counties of Nassau and Suffolk: Hauppauge, N.Y., $47 \mathrm{p}$.

Lounsbury, Clarence, Howe, F. B., Zautner, R. E., Moran, W. J., and Beers, P. D., 1928, Soil survey of Suffolk and Nassau Counties, New York: U.S. Department of Agriculture, Bureau of Chemistry and Soils, no. 28, 46 p.

Miller, J. F., and Frederick, R. H., 1969, The precipitation regime of Long Island, New York: U.S. Geological Survey Professional Paper 627-A, 21 p.

Prince, K. R., 1984, Streamflow augmentation at Fosters Brook, Long Island, New York--A hydraulic feasibility study: U.S. Geological Survey

Water-Supply Paper 2208, 43 p.

Porter, K. F., and Baskin, L. B., 1977, A recharge model for Nassau and Suffolk Counties, Long Island: Hauppauge, N.Y., Long Island Regional Planning Board, 78 p.

Reynolds, R. J., 1982, Base flow of streams on Long Island, New York: U.S. Geological Survey Water-Resources Investigations 81-48, 33 p.

Seaburn, G. E., 1969, Effects of urban development on direct runof $f$ to East Meadow Brook, Nassau County, Long Island, New York: U.S. Geological Survey Professional Paper 627-B, 14 p. 


\section{REFERENCES CITED (continued)}

Seaburn, G. E., and Aronson, D. A., 1974, Influence of recharge basins on the hydrology of Nassau and Suffolk Counties, Long Island, New York: U.S. Geological Survey Water-Supply Paper 2031, 66 p.

Steenhuis, T. S., Jackson, C. D., Kung, S. K. J., Brutsaert, W. H., and Cary, S. V., 1983, Water conservation and groundwater recharge on eastern Long Island: Ithaca, N.Y., Cornell University, 41 p.

Thornthwaite, C. W., and Mather, H. R., 1957, Instructions and tables for computing potential evapotranspiration and the water balance, in Drexel Institute of Technology, Publications in Climatology, v. 10, no. 3, p. $185-311$.

U.S. Department of Agriculture, 1975, Soil survey of Suffolk County, New York: Soil Conservation Service, $101 \mathrm{p}$.

U.S. Department of Commerce, 1974, Climates of the States, volume 1, Eastern States: National Oceanic and Atmospheric Administration, p. 257-280.

U.S. Geological Survey, 1967-76, Water resources data for New York, 1967-75, part 1, 1976, part 2, surface-water records: Albany, N.Y. (issued annually). 